\title{
A CLOSER LOOK ON DISCOURSE ANALYSIS BY USING SPEECH ACT THEORY AND HALLIDAYAN COHESION
}

\author{
Nabila Firda Asy'ari \\ Prodi Pendidikan Bahasa Inggris, FKIP, Universitas Lancang Kuning \\ nabilaafirda@yahoo.com
}

\begin{abstract}
This paper will describe and look out what speech act theory and Hallidayan cohesion to analyze a discourse. Here, the main point that we want to analyze is the spoken discourse. We will open what happens if we use speech act theory to analyze a discourse and what will happen if we use Hallidayan cohesion to analyze a discourse. We will know which one of these are the best or suitable to apply while analyzing a discourse. Is it speech act theory or Hallidayan cohesion? Then, in conclusion, we will also know why speech act theory is the best approach to analyze a discourse, especially spoken discourse.
\end{abstract}

Keywords: Discourse, Speech Act Theory, Hallidayan Cohesion

\section{INTRODUCTION}

This paper will describe and evaluate speech act theory and Hallidayan cohesion, the approaches to discourse analysis. Here, we will analyze text by using these approaches. Also, we will know which one of these approaches is the best to apply to analyze text. These approaches only concentrate on the function that makes easy to recognize and examine actions accomplished by people.

Before we try to analyze text or discourse using speech act theory and Hallidayan cohesion, we need to know what exactly discourse is. According to Salma Nouri on her paper "discourse can be defined as a special unit of language and specific focus on the use of language". Then, structure and function have relationship that chained with context and text. Functional here only focuses on context while structural focuses on text. However, structural take a bigger part of communication code. Then, Van Dijk stated that "Discourse Analysis can be done with spoken language since there is an evident interaction between the speakers; nevertheless, written materials can also be analyzed because readers assimilate what they are reading in spite of what may seem a passive interaction between the reader and the text".

According to Budianto Hamuddin, "the term "discourse" is a complex and mammoth-like interpretation. Many previous studies mention the term discourse as 
a very ambiguous since its introduction to modern science and the various broad interpretations discourse". He also stated that discourse refers to the speech patterns and how language, dialects, and acceptable statements are used in a community. Discourse as a subject of study looks at discourse among people who share the same speech conventions. Moreover, he stated that discourse refers to the linguistics of language use as a way of understanding interactions in a social context, specifically the analysis of occurring connected speech or written discourse. Then, in different paper, he mentioned that DA can play a valuable role in helping society to understand underlying meanings in texts, events, genre, or social practices.

In this paper, we will concentrate on the functional approaches to discourse which focus on function rather than structure. There are some approaches in this pattern like speech act theory, pragmatics, conversation analysis, and cohesion. But, we will focus on speech act theory and cohesion only.

Speech act theory is subfield in pragmatics focused on the words that we can use to carry out the actions of information. Like its name, speech act theory used to analyze direct discourse or spoken discourse. Brown and Yule (1983) said that the argument of Halliday and Hasan (1976) which stated that cohesion still got hesitant to differentiate the relation of meanings between items and obvious expression in a text. According to Halliday and Hasan, there's still evident relation to term that says every text has texture and it makes text looks different from other. Also, there is cohesion that included into a texture which makes text become clearer. In the other words, Halliday and Hasan just focus on the component that used while speaking.

Unfortunately, some experts feel that Halliday and Hasan cohesion theory not appropriate to apply in analyzing discourse or text because it does not describe the way to understand the meaning of a text.

\section{RESEARCH METHOD}

In doing the review, we looked for the related study which use database search that is Academia.edu and Google Scholars. Academia.edu is social networking which provides the member to share and download the document of a 
field. It can be a thesis, journal, article, or the other information are provided by adequate resources. Then, Google Scholars is a service provides the variety of subject for students in the variety of format text. So, the keywords like speech act theory, cohesion, and discourse analysis were chosen to complete the research.

\section{RESULTS AND ANALYSIS}

\section{Speech Act Theory: An Overview}

The language used to convey what human felt to other using expression that same with their emotions and it could be fickle by time. The way human speaking in a certain situation could affect their speech act. In speech act theory, we will know the aim of the utterance. Austin J. L, a linguist philosopher elaborated speech act theory. He and his friends created this theory as the opposition of the logical positivism philosophers of language. The core element of this theory is "we do not use language to tell only things, meaning to make statements, but also to do things to perform action" (Thomas, 1995: 28-31). Schifrin (1994) argued that speech act theory helps us to analyze how do meanings and acts are communicated linguistically. Then, there is J. R Searle stating the speech act theory in different perspective. He made a classification of condition we must have to make speech acts success. They are propositional, prefatory, sincerity, and essential. Also, he divided speech acts into five classes, they are declarations, expressive, representatives, directives, and commissives.

Some people think that Austin's and Searle's statement about the speech act theory is not connect each other. The difference of their speech act theory located at their different conceptions of an act. Austin's theory focuses more on the discourse's meaning that speaker said not the listener's interpretation of that discourse. In other hand, Searle's theory which is a development from Austin's theory still face some problem while analyze a discourse. His theory does not describe that there are different condition and grammatical form that will happen in a discourse. So that, using Austin's speech act theory in analyzing a discourse is more effective rather than using Searle's speech act theory. 
While we use language, there will be a meaning. In 1962, Austin distinguished meaning into three kinds, they are:

a. Locutionary meaning, which is the literal meaning of the statement of utterances.

b. Illocutionary meaning, it is a speaker intention which is the social aspect of the statement. Here, one statement could have more than one meaning.

c. Perlocutionary meaning, which takes a role as the result of the statement that has been told.

For the example those, here the example:

$$
\text { It's hot here }
$$

In locutionary meaning, it means that the situation is hot. Locutionary meaning only focuses on the real-life context. Whilst in illocutionary meaning which a statement or expression has more than one meaning or sense. The expression it's hot here could means someone asks for other person to open the window or turn on air conditioner indirectly. Then, it could mean someone rejects to open the window because it is summer outside that makes warm air enter the room. Also, it could mean an expression of complains why does situation or condition in a room be hot? or why does the window close? Next, in perlocutionary meaning which gives the result of a statement or an expression, that expression gives the result which someone will go to open the window or even turn on the air conditioner to cool up the room.

Because of that, we need to know what speaker means by replying their statement also give the result of what the speaker means by stating that expression. Then, the stress and intonation that used by speaker while stating this expression also give or show the actual meaning that speaker wants to tell. If the speaker uses flat intonation or maybe down, it means the speaker just want to describe the condition there. The speaker only wants to inform that in this room is hot. In other situation, if the speaker uses high intonation and gives stress to word "hot", it could mean the speaker ask someone to open the window or turn on the air conditioner. 
Or even, the speaker only complaining why does the situation he is hot. But, in context asking someone's help, we need to start or end it with lexical "please" to show our politeness. Out of it, the expression "it's hot here" usually used by people rather than adding lexical "please" in such statement like that. Because of this, we usually found and face the ambiguity of an expression that someone said.

\section{Exploring Hallidayan Cohesion}

The hearer of an English passage will know easily if a passage is linked correctly or not. Halliday and Hasan classified cohesive into two, they are according to the option of form that used and according to its nature. Cohesion itself means that in a text each sentence on a passage needs to link one another.

To know more about Hallidayan Cohesion in analyzing a discourse especially in spoken, let's see example below:

Anne: So, Kelly.

Kelly: Yes, Anne

Anne: You're on probation, are you?

Kelly: Sometimes I feel that way. I am a probation officer.

In the example above, Kelly and Anne are the speakers. Anne starts the conversation by saying "So, Kelly". Here the lexical "so" take a role to get Kelly's attention and lexical "Kelly" refers the name of a girl who has a conversation with Anne.

Then, Kelly as the conversation partner replied "yes, Anne" to Anne's statement. The using of lexical "yes" here means that Kelly gives attention to Anne's statement and want to know more what exactly Anne wants to know. After that, Anne gives a question to Kelly that asks her if she is on a probation. The using of "you" means that Anne gives a question that refers to Kelly's status or activity. And, the use of "are you?" gives more stress to the question. Not only that, the use of lexical "you" is a pronoun form subject "Kelly". About this, Halliday and Hasan stated that the use of pronoun can make a small set of option in a certain speech situation that relevant. 
By hearing Anne's question for her, Kelly needs to have knowledge or experience to understand Anne's question. So that, the role of knowledge and experience are important to understand a statement from our conversation partner. Here, Kelly as Anne's conversation partner reply to Anne's question by saying "Sometimes I feel that way" that means Kelly try to describe what she feels related to Anne's question based on her experience. Phrase "that way" which said by Kelly refers to probation that has been asked by Anne. Same with the previous expression that said by Anne, the use of pronoun can replace a lexical to another form. Finally, Kelly then stated "I am a probation officer" to make her first statement clearer. That she states clearly, she now a probation officer.

\section{CONCLUSION}

In conclusion, to analyze a discourse especially the spoken one, it suitable for us to use speech act theory rather than Hallidayan Cohesion. Speech act theory can analyze a text based on the situation and purpose of speaker's statement. But Hallidayan cohesion only focuses on a sentence that links to other sentences. Halliday and Hasan think that the hearer will suppose the success of sentences will form a text. They still have doubt about the meaning of a text and the expression that followed in the text. So that, it is suitable for us to use speech act theory to analyze discourse than Hallidayan cohesion.

\section{ACKNOWLEDGEMENTS}

I would like to say thank you to Allah SWT that have given me health and opportunity to conduct this paper. Then, I would like to deliver my gratitude to my supervisor and my dean who have trusted me to conduct this paper and finish it. Also, thank you to all lecturers in English Department FKIP Lancang Kuning University who have given valuable contribution to this study. Furthermore, I would like to deliver my gratitude to the Faculty which supported and funded this study. 


\section{REFERENCES}

Halliday, M. A. K. \& Hasan, R. (1976). Cohesion in English. Harlow: Longman.

Schifrin, D. (1994). Approaches to Discourse. Oxford: Blackwell.

Searle, J. (1969). Speech Acts. Cambridge: Cambridge University Press.

Bianku, Salma Nouri. Discourse Analysis by Using Speech Act Theory and Hallidayan Cohesion.

Hamuddin, Budianto, Faridah Noor Mohd Noor. (2015)."A Closer Look on Politeness Strategies in Malaysian Economic Journal." 2nd International Seminar on Linguistics.

Hamuddin, Budi. (2015). "DISCOURSE ON MEDIA: Bringing Hot News into ELT's Classroom Discussion." Proceedings of ISELT FBS Universitas Negeri Padang 3: 87-95. 